\title{
Gone and forgotten: facilitative effects of intercropping combinations did not carry over to affect barley performance in a follow-up crop rotation
}

\author{
Amit Kumar ${ }^{D} \cdot$ Christoph Rosinger $\cdot$ Hao Chen • \\ Siobhan Protic • Michael Bonkowski [ \\ Vicky M. Temperton 1 (1)
}

Received: 12 April 2021 / Accepted: 26 July 2021 / Published online: 12 August 2021

(C) The Author(s) 2021, corrected publication 2022

\begin{abstract}
Aim Intercropping often leads to improved productivity of individual species compared to monocultures. We have practically little knowledge of facilitation effects in different intercropping systems and their importance in creating soil legacies that can indirectly affect the succeeding crop in a crop rotation through plant-soil feedback (PSF) effects.

Methods To test this, we used a two-phased field experiment where we combined intercropping and crop rotation. During intercropping, we grew maize, faba bean, and lupine in monocultures or two-species crop combinations. The following season, we grew winter barley on the soil previously used for intercropping to test PSF effects under field conditions.

Results We found evidence for facilitative effects on aboveground biomass production that were
\end{abstract}

Responsible Editor: Kenny Png.

Supplementary Information The online version contains supplementary material available at https://doi. org/10.1007/s11104-021-05104-7.

A. Kumar $(\bowtie) \cdot$ S. Protic $\cdot$ V. M. Temperton Institute of Ecology, Faculty of Sustainability, Leuphana University Lüneburg, Universitätsallee 1, 21335 Lüneburg, Germany

e-mail: kumar@leuphana.de; aksoni089@gmail.com

C. Rosinger $\cdot$ H. Chen $\cdot$ M. Bonkowski

Cologne Biocenter, University of Cologne, Zülpicher

Straße 47b, 50674 Cologne, Germany species-specific with faba bean and maize biomass benefitting when intercropped compared to their expected biomasses in monocultures. Lupine, in contrast, performed best in monocultures. After the intercropping phase, total soil mineral nitrogen was higher in legume monocultures creating soil legacies but this did not affect soil microbial parameters and barley biomass production in the follow-up rotation phase.

Conclusions We found support for species-specific positive and negative interactions in intercropping. Our results also demonstrated that soil legacies play no significant role under moderately high nutrient environments.

Keywords Soil legacies · Plant-soil feedback effects · Arbuscular mycorrhiza colonization · Enzyme activities $\cdot$ Microbial biomass $\cdot$ Belowground interactions

\section{Introduction}

To meet the projected food demand by 2050 , agricultural production must increase by $60-110 \%$ and this increase should be environment-friendly through reduced usage of synthetic pesticides and fertilizers and increased ecological intensification (Tilman et al. 2011; Wezel et al. 2014). In this regard, Gurr et al. (2016) showed evidence that ecological intensification can be promoted by crop diversification. Through crop diversification, increasing the positive 
biodiversity effects, that is, higher productivity in mixed cultures than the corresponding monocultures, may help us enhance the ecological intensification. We have demonstrated knowledge where increasing plant species richness has shown to increase multiple ecosystem functions in forest (Huang et al. 2018) and grassland (Isbell et al. 2017) ecosystems. This knowledge may be applied in cropping systems to boost agricultural productivity. However, differences in experimental designs and management practices in both forest \& grassland ecosystems and cropping systems make it difficult to apply the knowledge gained from the former to cropping systems. For instance, in cropping systems, different intercropping types (relay-, strip- and mixed intercropping) and planting densities have been used, whereas, in most of the biodiversity-ecosystem functioning experiments, planting densities remain constant whereas the proportion of plant species vary. Further, the cropping systems remain intensively managed as compared to forest and less intensive grasslands. Therefore, we require more evidence from cropping systems on relative biomass production with different crop combinations as regards the strength of facilitative interactions leading to enhanced productivity. In situations where facilitation is particularly strong, one could envisage that its effects may even carry over into a subsequent crop.

In cropping systems, crop diversification can be achieved either spatially by growing more than one cultivar or crop simultaneously in close proximity (intercropping) or temporally by growing different consecutive crops (crop rotation). The positive effects of intercropping are mediated through trait complementarity and plasticity as well as the facilitative effects of interacting plant species (summarized in $\mathrm{Li}$ et al. 2014) whereas, for crop rotation, such effects are mediated through indirect feedback interactions (Schnitzer et al. 2011; Mushonga et al. 2020). There is more evidence on the positive spatio-temporal crop diversification on plant productivity (Li et al. 2014; Gaudin et al. 2015; Zhang et al. 2017; Dong et al. 2018), but negative effects have also been observed (Polley et al. 2003; Bukowski et al. 2018). This suggests that such effects appear to be species-specific and to a larger extent depend on soil biotic and abiotic properties as well as environmental conditions (Van der Putten et al. 2013; Craven et al. 2016; Png et al. 2019). For instance, by growing 4 barley cultivars (Prague, Spire, Waggon, and Krystal) and 3 legumes
(Trifolium subterranaeum, Ornithopus sativus, and Medicago trunculata) in monocultures and possible intercropping combinations, Darch et al. (2018) showed that, compared to monocultures, barley-legume intercropping resulted in an up to $40 \%$ increase in overall biomass production (combined of both crops in intercropping). This increase was dependent on soil $\mathrm{P}$ availability, with the highest gain occurring at or below the sub-critical P demand for barley. They further showed that intercropping of different cultivars of barley did not change their productivity compared to when growing in monocultures. Su et al. (2014) showed that even though the total chlorophyll content (chlorophyll a+chlorophyll b) of two soyabean cultivars increased in a relay intercropping with maize, the photosynthetic activity decreased as compared to their monocultures. This decreased photosynthetic activity was attributed to shading effects of maize. In an another wheat/maize relay intercropping system, the SPAD values (measure of leaf greenness) of maize decreased when intercropped with wheat ( $\mathrm{Li}$ et al. 2020). This suggests that it is not always the bigger plant in the mixed cultures that suppress the growth of the 'subordinate' plant. The underlying mechanisms still need to be identified.

The cornerstone of crop rotation practices lies on the assumption of plant-soil feedback (PSF) effects, that is, a preceding plant alters the soil abiotic and biotic components that may ultimately affect succeeding plant performance (Bever 1994; Ehrenfeld et al. 2005). It has been shown how PSF effects contribute to overyielding in intercropping and the succeeding crops by altering soil microbial communities (Wang et al. 2017, 2020). As microbiome assemblages in the soil appear to be generally plant species-dependent (Panke-Buisse et al. 2015; Uroz et al. 2019), it is believed that having phylogenetically distinct preceding and succeeding plant species may disrupt the species-specific pathogen accumulation in soil, thereby resulting in negative PSF effects (better plant performance in soil previously grown with different species) (Bever 2003; Miller et al. 2019; Heinen et al. 2020). This ideology is not strongly supported by either empirical (Fitzpatrick et al. 2017; Ingerslew and Kaplan 2018; Kaplan et al. 2020) or synthesis (Mehrabi and Tuck 2015) evidence. For example, Ingerslew and Kaplan (2018) demonstrated using the PSF approach that the succeeding plant biomass (tomato) strongly depended on the identity of 36 plant 
species that previously trained the soil. However, this effect was independent of phylogenetic relatedness of tomato with the preceding plant species.

These findings urge us to identify optimal crop species combinations in intercropping as well as in the rotation with an overall positive interaction effect on both above- and belowground yields and processes, irrespective of their phylogenetic relatedness. As most of the biodiversity-ecosystem functioning and PSF effects knowledge is derived from noncropping systems, we have limited knowledge if these ecological interactions and underlying mechanisms can also be utilized in cropping systems to enhance productivity through ecological intensification. More specifically, there have been limited attempts to combine spatio-temporal diversity (intercropping together with crop rotation) in cropping systems (KarpensteinMachan and Stuelpnagel 2000; Scalise et al. 2015; Wang et al. 2017, 2020; Kaplan et al. 2020). It is also not clear if different crop species that are performing better when intercropped would also create a positive soil legacy by improving soil nutrient contents, dilution of soil borne pathogens, and increased abundance of mutualists (e.g. arbuscular mycorrhizal fungi) that later would benefit the next crop in the rotation. It has recently been shown that identity of previous crop may lead to changes in AMF communities in soil that may persist over time to affect the follow-up crop (Roy et al. 2021). To fill this knowledge gap, we performed a field experiment comprising of two phases: an intercropping phase followed by a crop rotation phase. The intercropping phase consisted of monocultures and intercrops (a combination of two crops) of maize, faba bean, and lupine. The rotation phase had barley monocultures grown on soils from intercropping phase. The overall aim was two-fold: (1) identify the crop combinations in intercropping with overall enhanced biomass production relative to their expected biomasses in monocultures, and (2) to test the PSF effects of intercropping on soil biochemical parameters and barley biomass production in the rotation. Therefore, we hypothesized that:

1. Compared to monocultures, intercropped species will have a greater aboveground biomass production.

2. Intercropping would alter soil properties and create soil legacies which, in turn, affect the micro- bial parameters \& the performance of the next crop in the rotation through PSF effects.

\section{Materials and methods}

Experimental design and management

The field experiment started in May 2019 in an agricultural field in Lüneburg (53 $12^{\prime} \mathrm{N}$ and $\left.10^{\circ} 22^{\prime} \mathrm{E}\right)$, Germany. The climate is typical of temperate regions with mild summers and cold winters. The daily mean temperature and precipitation are shown in Supplementary Fig. 1. The agricultural field was under conventional practices with $800 \mathrm{~kg} \mathrm{ha}^{-1}$ chalk lime, 470 HAS (Harnstoff-Ammonsulfat) solution containing $20 \% \mathrm{~N}$ and $6 \% \mathrm{~S}$, and $300 \mathrm{~kg} \mathrm{ha}^{-1}$ Caralonkali containing $12 \%$ P $30 \% \mathrm{~K}, 6 \% \mathrm{Mg}$, and $4 \% \mathrm{~S}$ applied for summer barley in 2018. Soil was slightly acidic $\left(\mathrm{pH}_{\mathrm{H} 20} 6\right)$ and classified as Cambisol and contained around $2.1 \%$ total $\mathrm{C}$ and $0.2 \%$ total $\mathrm{N}$. The experiment comprised of block design in which five blocks were placed parallel to each other and six plots of $2 \times 2 \mathrm{~m}$ were randomly placed inside each block, yielding a total of five replicates per monoculture and intercrop combination. In each block, plots were $1 \mathrm{~m}$ apart from each other to avoid edge effects. The experiment consisted of two phases: an intercropping phase and a rotation phase.

Phase 1: intercropping phase

Maize (Zea mays L. cv. Colisee), faba bean (Vicia faba L. cv. Tiffany), and white lupine (Lupinus albus L. cv. Energy) were grown in monocultures and intercrops of two species combinations (Fig. 1). Crops were grown in rows and intercrops had alternating rows of each species. Monocultures of maize (M-M), faba bean $(\mathrm{Fb}-\mathrm{Fb})$, and lupine (L-L) had planting densities of 12,42 , and 42 plants $\mathrm{m}^{-2}$, respectively. In intercropping (maize + faba bean $(\mathrm{M}-\mathrm{Fb})$, maize + lupine (M-L), and faba bean + lupine ( $\mathrm{Fb}-\mathrm{L})$ ), the planting density of each species was reduced to half $\left(6,21\right.$, and 21 plants $\mathrm{m}^{-2}$ for maize, faba bean, and lupine, respectively). All crop species were sown simultaneously within 2 days (9th and 10th May 2019) and crop weeds were removed weekly during the growing season. 


\section{Phase 1: Intercropping}

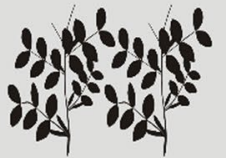

Faba bean (Fb-Fb) Monoculture (42 plants $\mathrm{m}^{-2}$ )
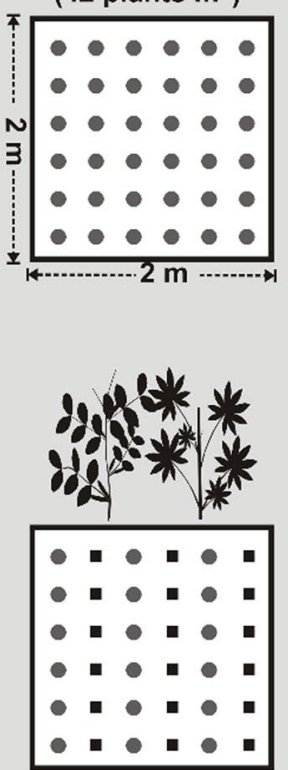

Faba bean-Lupine (Fb-L) Mixed culture (42 plants $\mathrm{m}^{-2}$ )

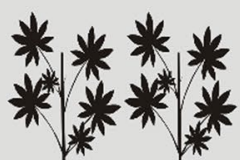

Lupine (L-L) Monoculture (42 plants $\mathrm{m}^{-2}$ )
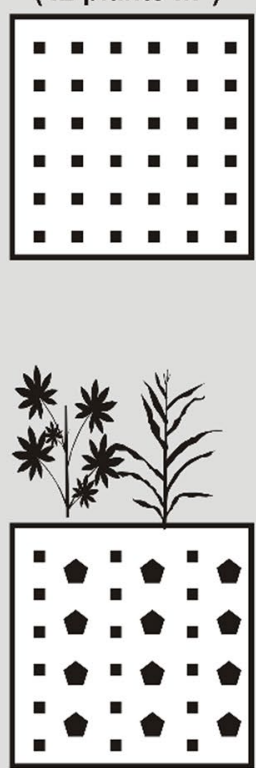

Maize-Lupine (M-L) Mixed culture (27 plants $\mathrm{m}^{-2}$ )

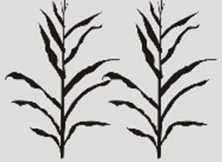

Maize (M-M)

Monoculture

(12 plants $\mathrm{m}^{-2}$ )

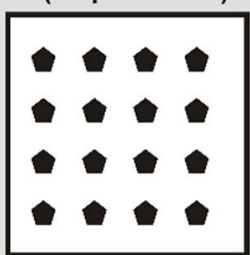

11
0
0
$\frac{1}{6}$
0

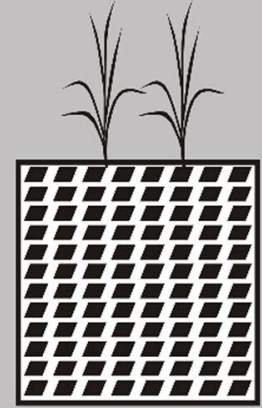

Winter Barley

Monocultures (300 plants $\mathrm{m}^{-2}$ )
Maize-Faba bean (M-Fb)

(27 plants $\mathrm{m}^{-2}$ )
Phase 1: Intercropping

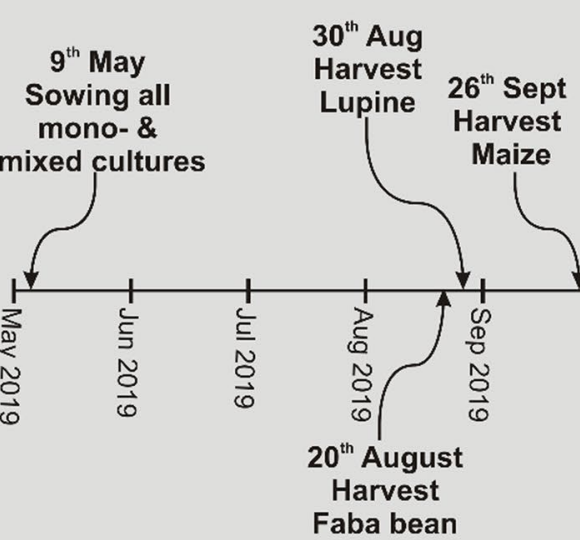

\section{Phase 2: Crop rotation}

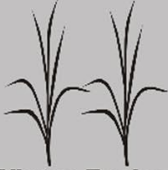

Winter Barley

Monocultures

( 300 plants $\mathrm{m}^{-2}$ )

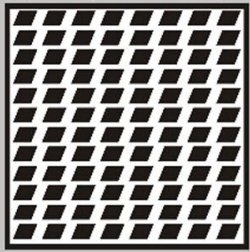

Phase 2: Crop rotation

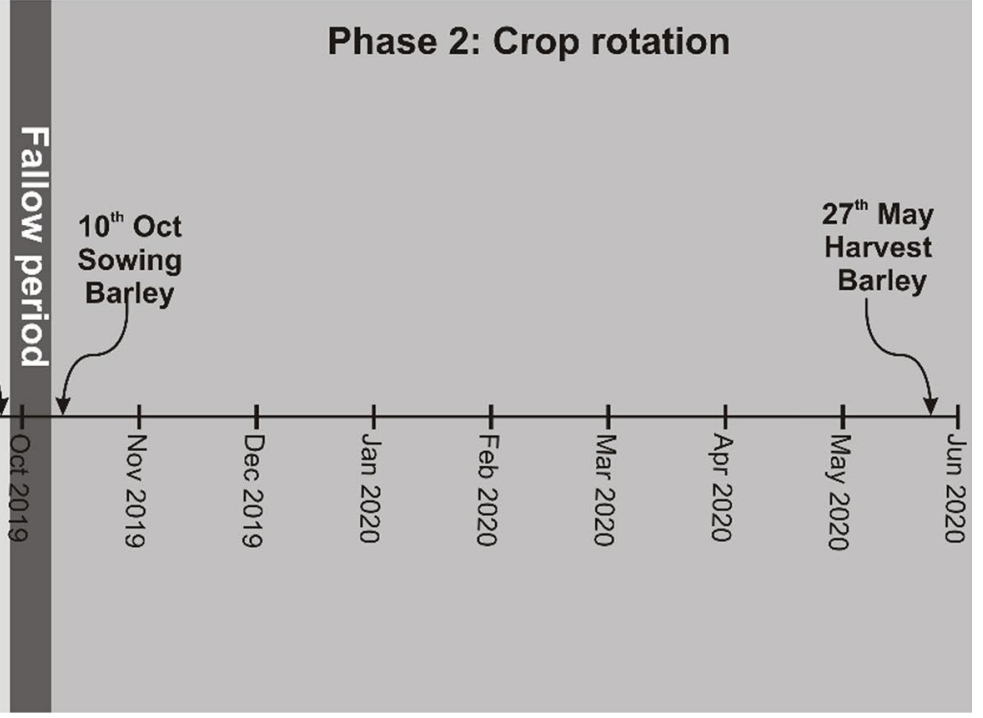


\Fig. 1 Upper panel shows the experimental design and layout with all the crop combinations and planting densities in monocultures and in the intercropping phase and that of barley in the subsequent rotation phase. The lower panel shows sowing and harvesting times for both the phases

\section{SPAD measurements}

Approximately on the 80th day after sowing, leaf greenness was measured as a proxy of chlorophyll content using a SPAD 502 Plus Chlorophyll Meter (SPAD-502-, Minolta Camera, Tokyo, Japan). We chose this time period as all the crop species were fully developed and were in their reproductive phase. For this, we randomly selected five plants from each crop species from both monocultures and intercrops. SPAD values were taken from two youngest yet fully developed healthy leaves at 10 points along the leaf length by avoiding edges and mid ribs. For faba bean and lupine, the measurements were distributed over the leaflets per leaf. Doing this, we had 4500 measurement points.

Harvest and soil sampling

On 20th and 30th August 2019, we harvested faba bean and lupine, respectively, whereas maize was harvested on 26th September 2019. This differential harvest date was chosen to allow complete maturity of each crop at harvest. We had initially planned to separate the grain yield from the total aboveground biomass at harvest, but due to a rust pathogen infection on the faba bean, we had to harvest before grain maturity. Since we did not have this separation in the faba bean, we decided in order to be consistent to treat all three species in the same way by measuring aboveground biomass. We randomly harvested 5, 10, and 10 plants of maize, faba bean, and lupine, respectively by cutting stem from soil surface towards the center of each plot to avoid edge effects at plot level. The harvested biomass was dried at $60{ }^{\circ} \mathrm{C}$ for 5 days to measure dry biomass and extrapolated to $\mathrm{kg} \mathrm{m}^{-2}$. The total aboveground biomass in intercrops for each species was calculated as difference between observed and expected values in intercrops compared to their respective monocultures to identify either positive or negative effects of intercropping on biomass production. For the expected aboveground biomass estimation for each crop species in intercrops, we halved their respective biomasses in monocultures to correct for planting density using paired monocultures and intercrops per block to account for block effects.

After maize harvest on 26th September 2019, all the plots experienced a fallow period of 12-13 days before rotation phase started (Fig. 1 lower panel). Prior to sowing winter barley in the rotation phase, we collected soil samples for loss-on-ignition and soil mineral $\mathrm{N}$ measurements to assess soil legacies created by intercropping phase.

Loss-on-ignition (LOI) was used as a proxy for soil organic matter (SOM). Pre-weighed fresh soil samples were first oven dried at $105^{\circ} \mathrm{C}$ for overnight to remove the moisture content. Pre- and post-ignition $\left(500{ }^{\circ} \mathrm{C}\right.$ for $24 \mathrm{~h}$ ) soil weight was recorded. Percent LOI was calculated as below:

LOI $(\%)=100 \times \frac{\text { pre } \cdot \text { ignition weight }(\mathrm{g})-\text { post } \cdot \text { ignition weight }(\mathrm{g})}{\text { pre } \cdot \text { ignition weight }(\mathrm{g})}$

For ammonium $\left(\mathrm{NH}^{4+}\right)$ and nitrate $\left(\mathrm{NO}^{3-}\right), 5 \mathrm{~g}$ of fresh soil were extracted in $20 \mathrm{ml}$ of a $0.01 \mathrm{M}$ $\mathrm{CaCl}_{2}$ solution. After horizontal shaking for $30 \mathrm{~min}$ and subsequent centrifugation (for $5 \mathrm{~min}$ at $4500 \mathrm{rpm}$ ) and filtration (through a Whatman 595 filter paper), ammonium and nitrate concentrations were immediately determined using ion-selective electrodes (Nico 2000 Ltd, UK).

Phase 2: rotation phase

We grew winter barley (Hordeum vulgare vr. Meridian) in the same plots which were used for the previous intercropping phase to investigate if barley performance is affected by soil legacy created by intercropping through PSF effects. For this, barley seeds were hand sown in rows on 10th and 11th October 2019 at a planting density of 300 seeds $\mathrm{m}^{-2}$. As it was impractical to hand-sow 30 plots of $2 \times 2 \mathrm{~m}^{2}$, we reduced the sowing area to $1 \times 2 \mathrm{~m}\left(2 \mathrm{~m}^{2}\right)$ per plot in the rotation phase. To facilitate sowing, we superficially ploughed all plots $(\sim 10 \mathrm{~cm}$ deep) and barley seeds were placed at $4-5 \mathrm{~cm}$ soil depth.

Harvest and soil sampling

Barley was harvested on 27th May 2020 from an area of $0.5 \times 0.25 \mathrm{~m}^{2}$. After harvesting barley, we randomly took 4 soil cores $(4 \mathrm{~cm}$ inner diameter and $10 \mathrm{~cm}$ depth) from the harvested area by placing the soil cores on the cut stem. This allowed us to collect 
soil and barley roots. Four cores were then pooled together to make one composite sample per plot and stored at $4{ }^{\circ} \mathrm{C}$ overnight before sieving ( $2 \mathrm{~mm}$ sieve) the next day. After the sieving process, the roots were transferred to $250 \mathrm{ml}$ plastic bottles containing distilled water and shaken overnight to remove soil adhering to roots. Afterwards, roots were carefully washed and stored in $90 \%$ glycerol for later counting for root length colonization by arbuscular mycorrhizal fungi.

Microbial biomass and potential enzyme activities

Sieved soil samples were used to measure microbial biomass $\mathrm{C}$ and $\mathrm{N}$ by chloroform-fumigationextraction with modifications (Vance et al. 1987; Witt et al. 2000). Two sets of subsamples (5 g) were taken from fresh samples. One set was horizontally shaken in $25 \mathrm{ml}$ of $0.5 \mathrm{M} \mathrm{K}_{2} \mathrm{SO}_{4}$ for $1 \mathrm{~h}$ and thereafter centrifuged for $5 \mathrm{~min}$ at $4500 \mathrm{rpm}$. Subsequently, $3 \mathrm{ml}$ of the supernatant were transferred to another plastic vessel and stored frozen until they were analysed for dissolved organic $\mathrm{C}$ (DOC) and total dissolved N (TDN) with a TOC analyser (multi N/C 2100S, Analytik Jena, Germany). The other set of samples was fumigated with $50 \mathrm{ml}$ of ethanol-free chloroform for $24 \mathrm{~h}$. After fumigation, soil extractions and $\mathrm{C}$ and $\mathrm{N}$ measurements were performed as described above. Soil microbial biomass $\mathrm{C}$ and $\mathrm{N}$ were determined as the difference of fumigated and non-fumigated DOC and TDN, respectively. Microbial biomass $\mathrm{C}$ and $\mathrm{N}$ were corrected by extraction efficiency factors of 0.45 (Vance et al. 1987) and 0.54 (Brookes et al. 1985), respectively.

\section{Microbial biomass $C$ (or $N)$

$$
=\frac{D O C(\text { or TDN })_{\text {fumigated soil }}-D O C(\text { or TDN })_{\text {non-fumigated soil }}}{K_{E C(0.45) \operatorname{or} E N(0.54)}}
$$

Potential activities of leucine aminopeptidase (LAP), $\mathrm{N}$-acetyl- $\beta$-D-glucosaminidase (NAG), $\beta$-glucosidase (GLU), and phosphomonoesterase (PHO) were measured fluorometrically according to the method described in Marx et al. (2001) and German et al. (2011). Briefly, $0.5 \mathrm{~g}$ of soil was suspended in $50 \mathrm{ml}$ sterile deionized water, homogenized for $1 \mathrm{~min}$ in a sonication bath, and aliquots of $200 \mu \mathrm{l}$ were subsequently pipetted under constant stirring into black 96-well microplates (Puregrade, Germany). Optimal substrate concentrations and incubation times for substrates were evaluated ahead. $50 \mu \mathrm{l}$ of substrate solution were added to each well, followed by a $120 \mathrm{~min}$ incubation in the dark at $20{ }^{\circ} \mathrm{C}$. Fluorescence was measured using a Perkin Elmer EnSpire multiplate reader with an excitation of $365 \mathrm{~nm}$ and an emission of $450 \mathrm{~nm}$. Potential enzyme activity was expressed in units of nmol MUB/AMC cleaved $\mathrm{g}^{-1}$ dry soil $\mathrm{h}^{-1}$.

Barley root length colonization by AMF

AMF abundance was determined as root length colonization in percent. Fresh roots stored in $90 \%$ glycerol were cut into $1-1.5 \mathrm{~cm}$ fragments and cleared in $10 \%$ $\mathrm{KOH}$ for $20 \mathrm{~min}$ in a water bath at $80{ }^{\circ} \mathrm{C}$. Afterward, roots were washed 4 times with distilled water and acidified for 10 min with $1 \% \mathrm{HCl}$ and placed in a $2 \%$ blue ink in $1 \% \mathrm{HCl}$ for $30 \mathrm{~min}$ at $80{ }^{\circ} \mathrm{C}$ before clearing them overnight in lactoglycerol (1:1:1) (Phillips and Hayman 1970; Vierheilig et al. 1998). Cleared root fragments were mounted on glass slides and the percent of root length colonization was quantified with the intersection method (McGonigle et al. 1990).

\section{Statistics}

All the statistical analyses were performed within $\mathrm{R}$ environment (Team 2020) and graphs were prepared with the 'ggplot2' (Wickham 2016) and 'ggpurb' (Kassambara 2020) libraries. The measured variables are presented as means with confidence intervals (CIs) of $95 \%$ that were computed by using non-parametric bootstrap resampling with 10,000 iterations. To avoid common statistical errors, we followed the step-wise protocol for data exploration (Zuur et al. 2010). The mean-variance relationship was visually checked from residual plots. We used 'glmmPQL' function from 'MASS' library (Venables and Ripley 2002) to fit generalized linear mixed models (GLMMs) followed by Type III ANOVA and Tukey's test for multiple contrasts to test if intercropping phase affected LOI, mineral $\mathrm{N}$, barley shoot biomass, root length colonization with AMF, microbial $\mathrm{C}$ and $\mathrm{N}$, and the potential activity of GLU, LAP, NAG, and PHO enzymes. For SPAD values, separate GLMMs were fit for each crop species followed by Type III ANOVA and Tukey's test for multiple contrasts as mentioned above. The absolute mean, bootstrap mean, and upper \& lower CIs of the 
measured values were computed with 'rcompanion' library (Mangiafico 2020). We refer to significant differences at the $p<0.05$ level but based on recent discussion on the significance and null hypothesis testing using $\alpha=0.05$, we refrain from using the word 'significant' and mostly mention the mean differences between the treatments and effect sizes wherever possible (Ho et al. 2019; Rillig et al. 2019).

\section{Results}

Phase 1: intercropping phase

\section{Aboveground biomass production and SPAD values}

Total aboveground biomass was affected in intercrops relative to their monocultures and this effect was crop-specific. Aboveground biomass of faba bean and maize increased when intercropped whereas that of lupine decreased in intercropping irrespective of crop combinations. This increase was $65 \%$ and $47 \%$ for faba bean when intercropped with maize and lupine, respectively (Fig. 2, Supplementary table 2). Similarly, maize aboveground biomass increased by $135 \%$ and $131 \%$ in intercropping with faba bean and lupine, respectively. On the contrary, the aboveground biomass of lupine decreased by $28 \%$ and $36 \%$ when intercropped with maize and faba bean, respectively. At the species level, we found greatest SPAD values for lupine and the values remained similar in both monoculture and when intercropped. On the other hand, faba bean and maize had greater SPAD values in their monocultures compared to their intercropping independent of species combination (Supplementary Figure 2).

\section{Legacy effects on soil properties}

The total SOM content was unaffected after intercropping phase (Fig. 3a). The mineral $\mathrm{N}$ in the soil, however, showed the legacy effects created from the intercropping phase (Fig. 3b). For instance, compared to maize monoculture, legume monocultures had higher mineral $\mathrm{N}$ content in the soil $38 \%$ higher in $\mathrm{Fb}-\mathrm{Fb}$ monoculture and $46 \%$ higher in L-L monoculture), whereas that of intercrops was in between.

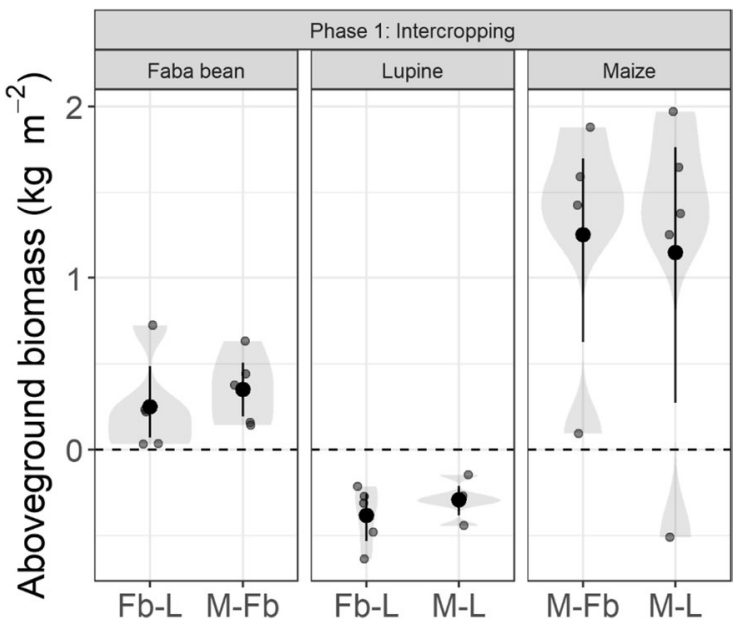

Fig. 2 Effect sizes of crop species combinations on observed aboveground biomass production in intercropped combinations. Dashed lines indicate aboveground biomass of the respective monoculture. Values are the absolute differences between intercrops and monocultures for each crop species. Positive and negative values for each species represent greater or lower aboveground biomass in intercropping than its corresponding monoculture. Values are the means and 95\% confidence intervals. Small dots represents individual replicates. $\mathrm{Fb}-\mathrm{L}$ : faba bean + lupine intercrop, $\mathrm{M}-\mathrm{Fb}$ : maize + faba bean intercrop, M-L: maize + lupine intercrop

Phase 2: rotation phase

\section{Microbial biomass and potential enzyme activities}

In the rotation phase, microbial biomass $\mathrm{C}$ and $\mathrm{N}$ remained similar and did not vary depending on the intercropping phase. The same was true for microbial biomass C:N ratios (data not shown). Similarly, the potential activities of four measured enzymes were not dependent on the soil legacies from the intercropping phase (Fig. 4).

Root length colonization by arbuscular mycorrhizal fungi

The percent root length of barley colonized by AMF (as determined by staining technique) was affected by the intercropping phase (Fig. 5). Barley grown in soil previously trained by maize-faba bean $(\mathrm{M}-\mathrm{Fb})$ crop combination had the highest root length colonization $(61 \%)$ followed by faba bean-lupine (Fb-L) 


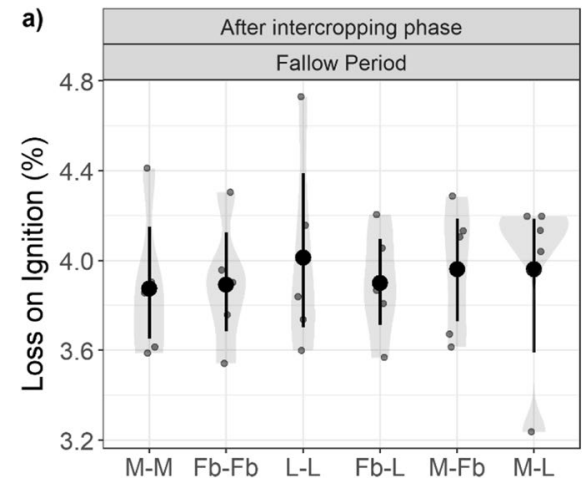

Fig. 3 a) Loss on ignition (\%) as a proxy for soil organic matter (SOM) and b) soil mineral $\mathrm{N}\left(\mathrm{mg} \mathrm{N} \mathrm{kg}^{-1}\right.$ soil) after the intercropping phase. Values are the means and $95 \%$ confidence intervals. Small dots represents individual replicates. M-M:

intercropping (56\%). Barley root length colonized by AMF was lower when grown in soil from monocultures and the maize-lupine (M-L) intercrops.

\section{Barley aboveground biomass production}

Barley aboveground biomass varied from 0.25 to $0.37 \mathrm{~kg} \mathrm{~m}^{-2}$ but the soil feedback effects from the intercropping phase had no effect on barley biomass production (Fig. 6).

\section{Discussion}

Positive effects of intercropping on aboveground biomass production are species-specific

In support of the first hypothesis, we showed positive effects of intercropping on aboveground biomass production and such effects were crop-specific and dependent on the exact combinations of species grown together (Fig. 2). Maize benefitted the most from facilitative interactions with the legumes. The mineral $\mathrm{N}$ accumulation that occurred only in legume monoculture plots underlines the importance of legume-grass interactions as strong candidates for creating facilitative interactions. Such crop-specific effects of intercropping on aboveground biomass production have previously been shown to be likely mediated by interspecific interactions and soil type

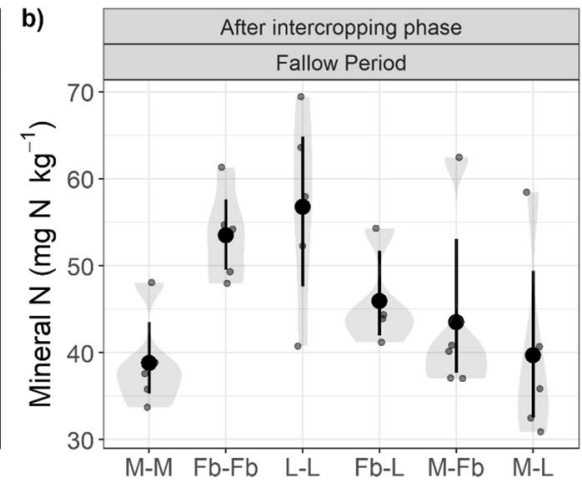

maize monoculture, $\mathrm{Fb}-\mathrm{Fb}$ : faba bean monoculture, $\mathrm{L}-\mathrm{L}$ : lupine monoculture, $\mathrm{Fb}-\mathrm{L}$ : faba bean + lupine intercrop, $\mathrm{M}-\mathrm{Fb}$ : maize + faba bean intercrop, M-L: maize + lupine intercrop. Refer to Supplementary table 1 for descriptive statistics

(Dissanayaka et al. 2015; Gou et al. 2016; Chen et al. 2019), with the underlying mechanisms varying with crop species identity. In intercropping systems of two crops growing simultaneously in close proximity, multiple scenarios may arise in terms of biomass production. For instance, in intercropping, (1) both crop species may benefit from each other thereby increasing their biomasses, (2) one crop species may benefit without affecting the performance of other species, (3) one species may benefit on the expense of other species, and (4) no benefit of intercropping on biomass production of both crop species.

In our study, we found that faba bean and maize had greater aboveground biomass production in in intercropping than their expected biomasses in monocultures (Fig. 2). Such stimulated productivity of maize and faba bean biomass has been attributed to inter-specific rhizosphere interactions, in which, root exudates from maize act as signaling molecules to induce faba bean root nodulation and consequently higher rates of biological $\mathrm{N}$ fixation (Li et al. 2016). Maize, on the other hand, gets access to soil nutrients such as $\mathrm{N}$ that is spared by faba bean but also to increased $\mathrm{P}$ availability through faba bean mediated by rhizosphere acidification ( $\mathrm{Li}$ et al. 2007; Zhang et al. 2016). It should also be noted that even though maize is found to be benefitting when intercropped with legumes (Sileshi et al. 2008; Chai et al. 2014; Latati et al. 2014), the aboveground biomass of maize 
a)

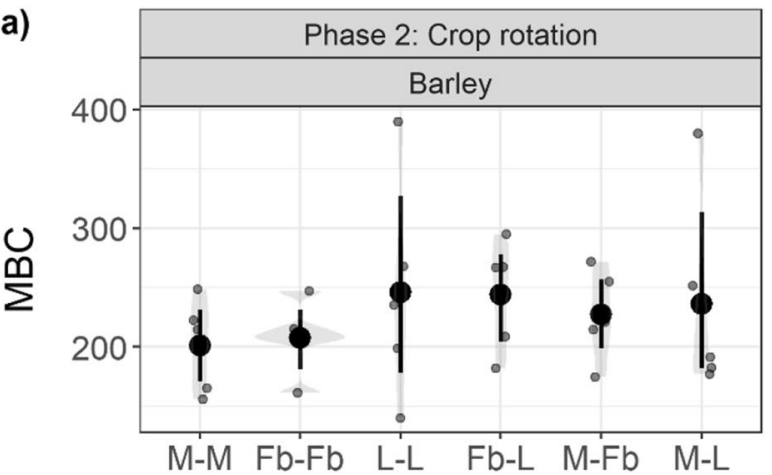

c)

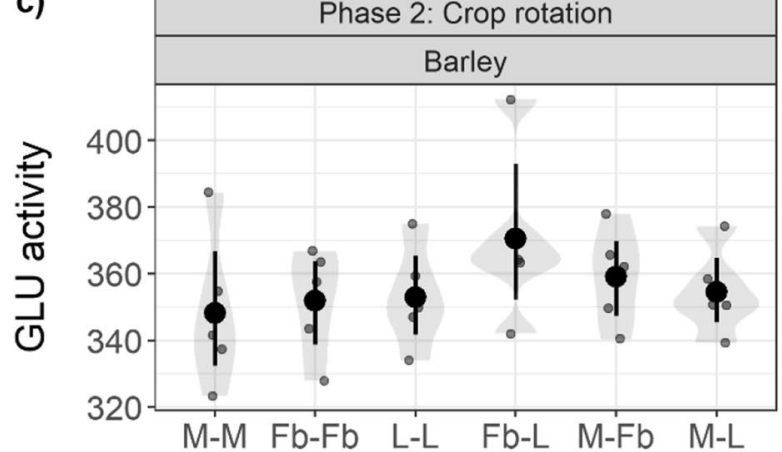

e)

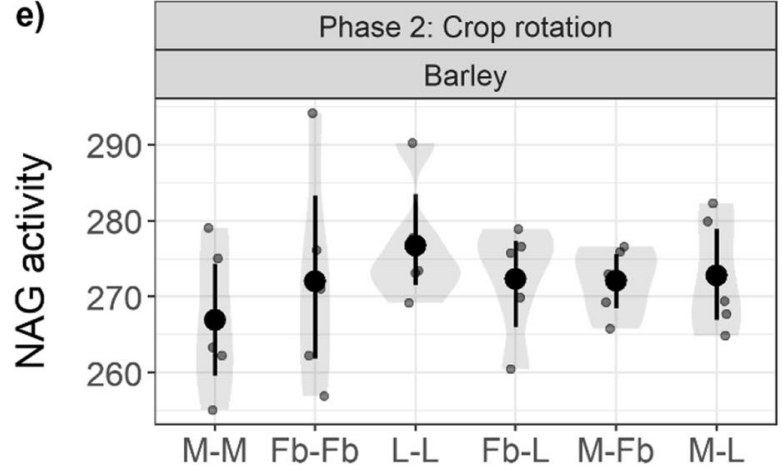

Fig. 4 a) Microbial biomass $\mathrm{C}$ (MBC, $\mathrm{mg} \mathrm{C} \mathrm{kg}^{-1}$ soil), b) microbial biomass $\mathrm{N}$ (MBN, $\mathrm{mg} \mathrm{N} \mathrm{kg}^{-1}$ soil), c) $\beta-1,4-$ glucosidase (GLU, nmol MUB cleaved $\mathrm{g}^{-1}$ soil $\mathrm{h}^{-1}$ ) activity, d) L-leucine aminopeptidase (LAP, nmol AMC cleaved $\mathrm{g}^{-1}$ soil $\mathrm{h}^{-1}$ ) activity, e) $\beta-1,4-\mathrm{N}$-acetylglucosaminidase (NAG, nmol MUB cleaved $\mathrm{g}^{-1}$ soil $\mathrm{h}^{-1}$ ) activity, and $\mathbf{f}$ ) phosphomonoesterase (PHO, nmol MUB cleaved $\mathrm{g}^{-1}$ soil $\mathrm{h}^{-1}$ ) activity in

was exceptionally high in intercropping in the present study. Along with facilitation, this increase may additionally be attributed to the lowered competition for resources as a result of early harvest of
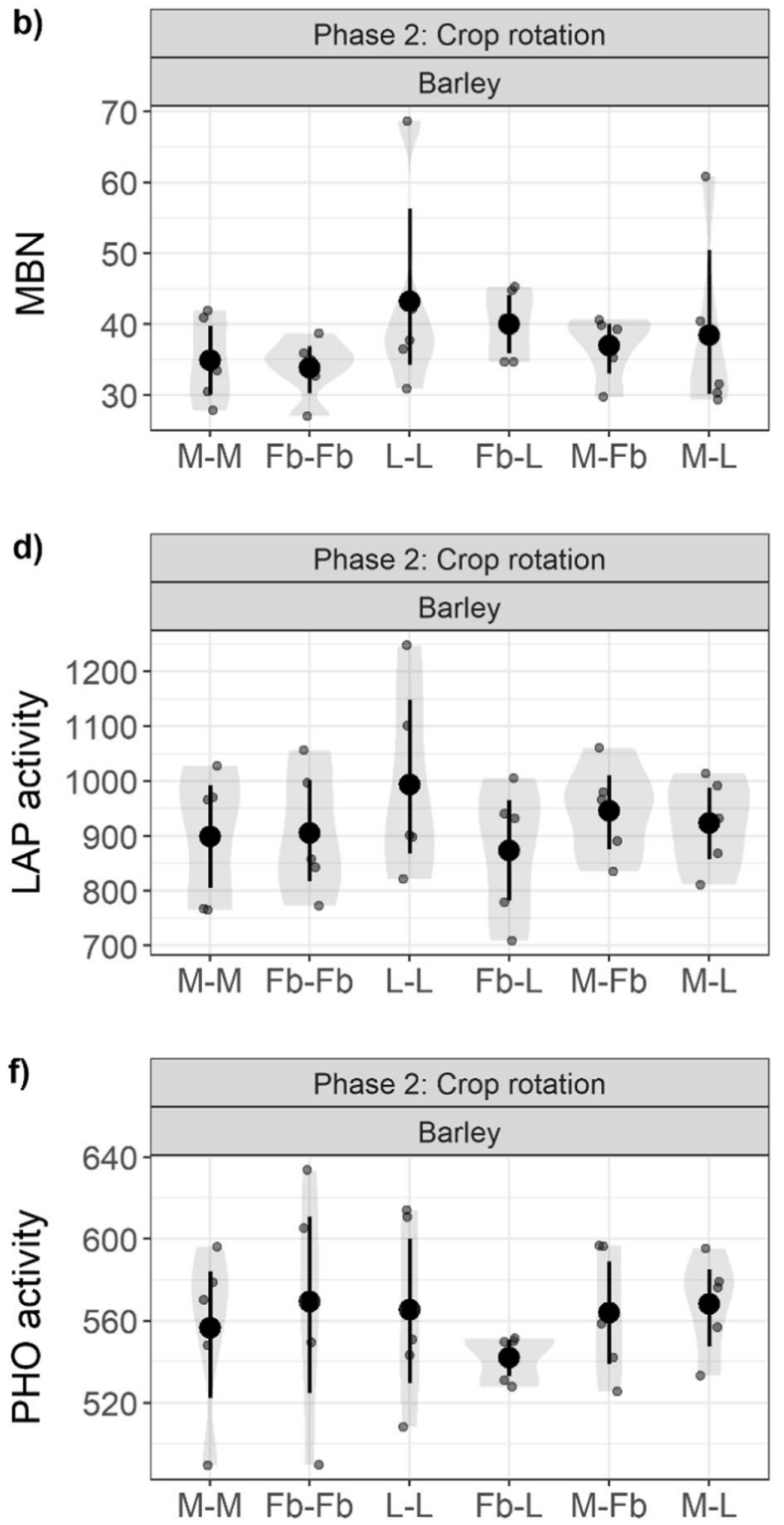

the rotation phase when grown on soils trained from intercropping phase. Values are the means and 95\% confidence intervals. Small dots represent individual experimental replicates. M-M: maize monoculture, Fb-Fb: faba bean monoculture, L-L: lupine monoculture, $\mathrm{Fb}-\mathrm{L}$ : faba bean + lupine intercrop, $\mathrm{M}-\mathrm{Fb}$ : maize + faba bean intercrop, M-L: maize + lupine intercrop. Refer to Supplementary table 1 for descriptive statistics

faba bean and lupine than maize as well as reduced maize planting density when intercropped. Such temporal differentiation due to different harvesting period has been shown to significantly contribute to 


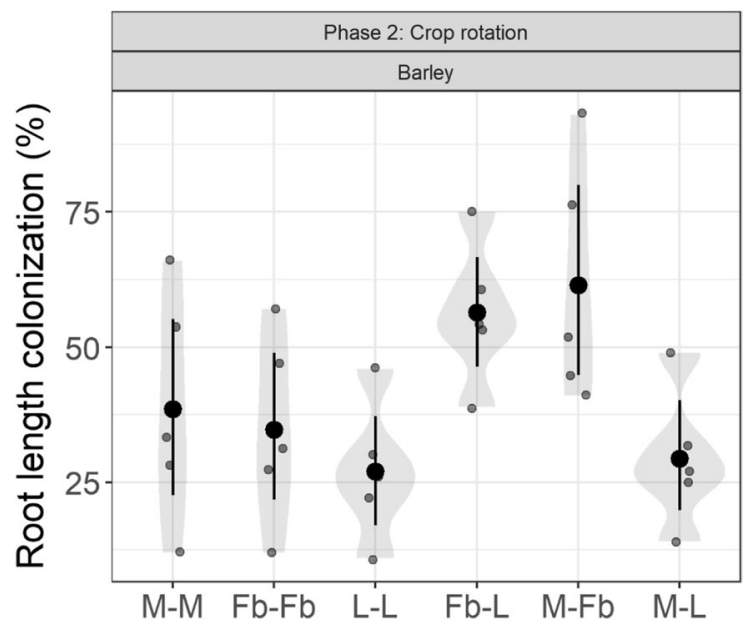

Fig. 5 Barley root length colonization (\%) by arbuscular mycorrhizal fungi in the rotation phase when grown on soils trained from intercropping phase. Values are the means and 95\% confidence intervals. Small dots represent individual experimental replicates. $\mathrm{M}-\mathrm{M}$ : maize monoculture, $\mathrm{Fb}-\mathrm{Fb}$ : faba bean monoculture, $\mathrm{L}-\mathrm{L}$ : lupine monoculture, $\mathrm{Fb}-\mathrm{L}$ : faba bean + lupine intercrop, $\mathrm{M}-\mathrm{Fb}$ : maize + faba bean intercrop, M-L: maize + lupine intercrop. Refer to Supplementary table 1 for descriptive statistics

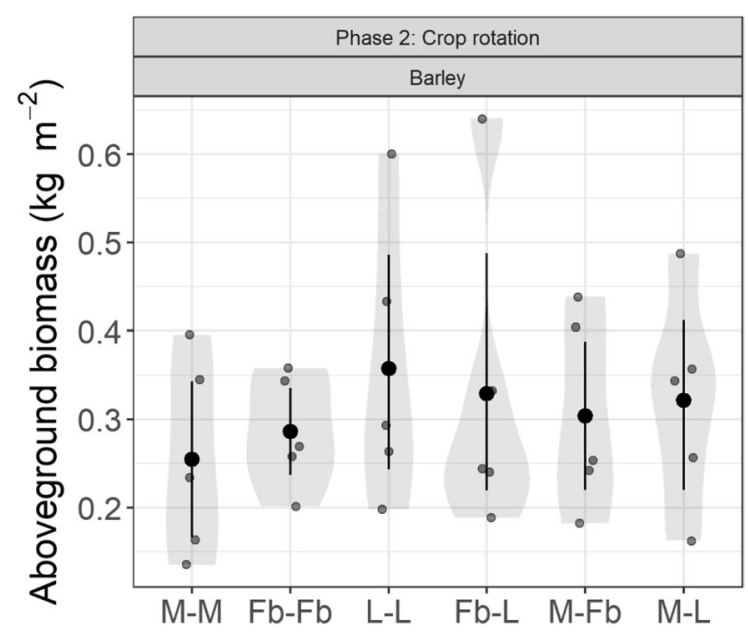

Fig.6 Barley aboveground biomass $\left(\mathrm{kg} \mathrm{m}^{-2}\right)$ in the rotation phase when grown on soils trained from intercropping phase. Presented are the means and $95 \%$ confidence intervals. Small dots represents individual replicates. M-M: maize monoculture, $\mathrm{Fb}-\mathrm{Fb}$ : faba bean monoculture, $\mathrm{L}-\mathrm{L}$ : lupine monoculture, $\mathrm{Fb}-\mathrm{L}$ : faba bean + lupine intercrop, $\mathrm{M}-\mathrm{Fb}$ : maize + faba bean intercrop, M-L: maize + lupine intercrop. Refer to Supplementary table 1 for descriptive statistics yield advantages in intercropping systems (Yu et al. 2015; Dong et al. 2018).

Next, we showed that when intercropped with lupine, the aboveground biomass production for faba bean and maize was greater (Fb-L and M-L) than their corresponding monocultures, whereas, the aboveground biomass of lupine decreased as compared to its monoculture. Lupines in nature tend to grow in large stands that dominate the surrounding vegetation, and hence evolutionarilyspeaking our results seem to underline this habit, in that it did not benefit from intercropping. The lower performance of lupine when intercropped also hints toward antagonistic inter-specific interactions negatively affecting lupine growth and is very likely that the competition for resources severely constrained lupine growth when intercropped. This notion is supported by the smaller SPAD values (a proxy for chlorophyll content) for faba bean and maize leaves in the intercropping than their corresponding monocultures whereas SPAD values were the highest and remained similar for lupine in both monoculture and intercropping with maize and faba bean. This finding indicated that energy and resource investments for photosynthetic activity was generally greater for lupine than both maize and faba bean and did not change depending on monocultures and intercropping. On the contrary, smaller SPAD values for maize and faba bean when intercropped may suggest reduction in inter-specific competition for resources and efficient resource investments in biomass production for both maize and faba bean. We are aware that SPAD values are only the measure for leaf greenness and the actual rate of photosynthesis in both monocultures and intercrops may vary. It has been shown that intercropping maize with lupine resulted in higher maize biomass production but there was a tendency of lower biomass for lupine (although not significant) compared to their monocultures (Dissanayaka et al. 2015). In support of our results, Hauggaard-Nielsen et al. (2008) found that narrow-leafed lupine (L.angustifolius L.) performance was lowered in intercropping with barley with a reduction in atmospheric $\mathrm{N}$-fixation from 15 to $5-6 \mathrm{~g} \mathrm{~N} \mathrm{~m}^{-2}$. Further investigations are required to quantify $\mathrm{C}$ costs for resource acquisition and biomass production for lupine before adopting lupine as a viable companion crop in intercropping and mixed cultures. 
Soil legacies from intercropping phase did not affect soil microbial parameters and barley aboveground biomass production in the rotation phase

We showed that variation in soil mineral $\mathrm{N}$ was dependent on the intercropping phase, thereby, created soil $\mathrm{N}$ legacies (Fig. 3). Mineral $\mathrm{N}$ was greater in legume monocultures (both $\mathrm{Fb}-\mathrm{Fb}$ and $\mathrm{L}-\mathrm{L}$ ) compared to maize monoculture, with in-between effect for intercropped combinations. This is very likely a result of residual $\mathrm{N}$ in soil from decomposition of high-N plant residues that was reported previously (Freschet et al. 2012). Lower $\mathrm{C}: \mathrm{N}$ ratios of legume residues make them faster to decompose by microbes. Legumes are also known to increase soil $\mathrm{N}$ availability through rhizodeposition (Fustec et al. 2009) and biological $\mathrm{N}$ fixation (Jensen and Hauggaard-Nielsen 2003) that leads to facilitative effects on neighbors (Temperton et al. 2007). Temperton et al. (2007) found that legume presence across a gradient of grassland plant diversity in the Jena Experiment facilitated a grass and a forb species, but the exact effect was largest for the grass, with the forb only increasing leaf $\mathrm{N}$ but not growing larger with legumes. Contrary to our expectation (i.e. higher mineral $\mathrm{N}$ in intercropped combinations than maize monoculture) we found comparable amounts of mineral $\mathrm{N}$ in maize monoculture (M-M) and all the intercrop combinations. This contrasts with previous findings showing that plants in mixed cultures extracted more nutrients from soil than those in monocultures due to complementarity in resource acquisition (Levine and HilleRisLambers 2009; Yang et al. 2013; Hacker et al. 2015; Wang et al. 2015). However, in the present study, this could be an artifact as we only measured the mineral $\mathrm{N}_{\left(\mathrm{NO}_{3}\right.}{ }^{-}$and $\left.\mathrm{NH}_{4}{ }^{+}\right)$ after the intercropping phase which does not represent all $\mathrm{N}$ pools in soil. Depending on cropping systems, discrepancies in total and (in)organic $\mathrm{N}$ pools have been reported suggesting alteration in soil $\mathrm{N}$ pools after intercropping (Cong et al. 2015; Wang et al. 2015). Future studies would need to also measure organic $\mathrm{N}$ pools and mineralization rates to better understand soil $\mathrm{N}$ dynamics in relation to relative importance of organic and mineral $\mathrm{N}$ in intercropping settings. Similar to mineral N, we expected that faster decomposition of legume residues would increase the fraction of their residues that becomes a part of the SOM thereby increasing the total SOM content in soil. However, we found that the total SOM remained similar after intercropping phase. This finding suggests that the legume-derived SOM fraction decomposed quickly without affecting the total pool of SOM. This is plausible as one would expect an increased pool of particulate organic matter during early decomposition stages which is characterized by faster decomposition than the mineral associated organic matter pool. We suggest that future studies directly quantify the litter decomposition and its contribution in the formation of stable SOM from different cropping systems.

Soil legacies from intercropping phase neither affected the microbial parameters measured nor the aboveground biomass of barley in the rotation phase, thereby rejecting our second hypothesis. We found that, in the rotation phase, microbial biomass $\mathrm{C}$ and $\mathrm{N}$, and their potential enzyme activities remained unchanged, suggesting an absence of strong PSF effects. In agreement with our findings, Wang et al. (2015) showed in a decade long mixed cropping experiment that even though the soil chemical parameters such as soil $\mathrm{pH}$, exchangeable potassium, and cation exchange capacity varied depending upon cropping systems (monocultures versus continuous and rotational mixed cultures), the soil biological parameters such as activities of urease, phosphomonoesterase, and nitrate reductase remained largely unaffected. In an another experiment under rainfed conditions, Scalise et al. (2015) showed that legume-cereal intercropping had rather low impact compared to soil type and environmental factors on succeeding durum wheat productivity. Our findings are in contrast with results from Barel et al. (2019), where the identity of preceding crop affected the microbial biomass in the succeeding cropping phase. These discrepancies may arise from different plant species and nutrient availability in different soil types under investigation. For example, total $\mathrm{N}$ and total $\mathrm{P}$ content was higher in the present study than that found in Barel et al. (2019), and soil nutrient availability has strong regulation on microbial community composition and their activities (Olander and Vitousek 2000; Bell et al. 2015; Kumar et al. 2018) as well as the PSF effects (in't Zandt et al. 2019; Klinerová and Dostál 2019).

No change in barley aboveground biomass production in the rotation phase suggests that PSF effects are context dependent and edaphic factors 
may, in part, play a significant role. It further suggests that the generally observed positive plant-microbial interaction and plant performance in nutrient-limited soils may fade with higher nutrient availability. Our results are supported by a recent study (in't Zandt et al. 2019), where PSF effects on shoot biomass production of four grassland species were neutralized under increased nutrient availability. Interestingly, we found variation in the barley root length colonized by AMF but this did not lead to a measurable benefit (higher biomass production) for barley. This is in line with the long-held view that under higher nutrient availability, plants are less dependent on AMF for nutrient acquisition (Treseder 2004; Camenzind et al. 2016). Altered AMF colonization of barley roots may be due to changes in their community composition from intercropping phase. AMF communities have been shown to co-vary with their host plant community composition and diversity (Schmid et al. 2020; Smilauer et al. 2020). Therefore, it is very likely that soil harbored differential AMF communities from intercropping phase, which may have varied in the degree of root colonization potential.

\section{Conclusions}

We found evidence for good intercropping species combinations (maize and faba bean) as well as not so effective intercropping combinations (with lupine), with species-specific increases in biomass production in intercropping despite relatively high nutrient content in the agricultural soil. This suggests that inter-specific interactions overwhelmed the soil nutrient availability. Density-dependent relaxation in competition with maize in the intercropped combinations may have further resulted in increased biomass production but this was the case only for faba bean and not for lupine. Although belonging to the same plant functional group (i.e. legume), our study underlines that faba bean and lupine have a different potential in intercropping systems for biomass production. Further, we showed that the feedback effects of intercropping did not lead to improved barley biomass production even if there were changes in residual mineral $\mathrm{N}$ after the intercropping phase. These effects were also similar for other biological parameters (microbial biomass and their potential enzyme activity) in the rotation phase. Even though we showed that intercropping did not lead to significant PSF effects in our study, such effects may become important in management practices promoting reduced external mineral inputs or in soils with low fertility.

Acknowledgements We greatly acknowledge field assistance from Thomas Niemeyer, Christoph Stegen, Vladimir Vakhtinskii, Pola Rief, Laura Störzer, Hannes Schempp, Johanna Wille, and Mira Hesselman. This research was financed by the BonaRes soil sustainability program of the German Ministry of Education and Research (BMBF) within the 'INPLAMINT - Increasing agricultural nutrient-use efficiency by optimizing plant-soil-microorganisms interactions' project with the grant numbers: 031B0508H and 031B0508F. Authors would like to sincerely thank the editor and three anonymous reviewers for their insightful comments and suggestions.

Author contribution AK and VMT designed the experiment. AK collected field data and led lab measurements. CR and $\mathrm{HC}$ measured mineral $\mathrm{N}$, microbial biomass, and potential enzyme activities. SP took SPAD measurements for leaf greenness. AK analyzed all the data and prepared the first draft. All coauthors read and contributed to finalize the manuscript, and gave their permission for submission.

Funding Open Access funding enabled and organized by Projekt DEAL.

Data availability Should the manuscript be accepted for publication, the presented data will be submitted to BonaRes data repository (https://datenzentrum.bonares.de/data-portal. php).

\section{Declarations}

Conflict of interest Authors declare no conflict of interest for this submission.

Open Access This article is licensed under a Creative Commons Attribution 4.0 International License, which permits use, sharing, adaptation, distribution and reproduction in any medium or format, as long as you give appropriate credit to the original author(s) and the source, provide a link to the Creative Commons licence, and indicate if changes were made. The images or other third party material in this article are included in the article's Creative Commons licence, unless indicated otherwise in a credit line to the material. If material is not included in the article's Creative Commons licence and your intended use is not permitted by statutory regulation or exceeds the permitted use, you will need to obtain permission directly from the copyright holder. To view a copy of this licence, visit http://creativecommons.org/licenses/by/4.0/. 


\section{References}

Barel JM, Kuyper TW, Paul J et al (2019) Winter cover crop legacy effects on litter decomposition act through litter quality and microbial community changes. J Appl Ecol 56:132-143. https://doi.org/10.1111/1365-2664.13261

Bell CW, Asao S, Calderon F et al (2015) Plant nitrogen uptake drives rhizosphere bacterial community assembly during plant growth. Soil Biol Biochem 85:170-182. https://doi. org/10.1016/j.soilbio.2015.03.006

Bever JD (1994) Feeback between plants and their Soil communities in an old field community. Ecology 75:1965-1977

Bever JD (2003) Soil community feedback and the coexistence of competitors: Conceptual frameworks and empirical tests. New Phytol 157:465-473. https://doi.org/10.1046/j. 1469-8137.2003.00714.x

Brookes PC, Landman A, Pruden G, Jenkinson DS (1985) Chloroform fumigation and the release of soil nitrogen: a rapid direct extraction method to measure microbial biomass nitrogen in soil. Soil Biol Biochem 17:837-842. https://doi.org/10.1016/0038-0717(85)90144-0

Bukowski AR, Schittko C, Petermann JS (2018) The strength of negative plant-soil feedback increases from the intraspecific to the interspecific and the functional group level. Ecol Evol 8:2280-2289. https://doi.org/10.1002/ ece 3.3755

Camenzind T, Homeier J, Dietrich K et al (2016) Opposing effects of nitrogen versus phosphorus additions on mycorrhizal fungal abundance along an elevational gradient in tropical montane forests. Soil Biol Biochem 94:37-47. https://doi.org/10.1016/j.soilbio.2015.11.011

Chai Q, Qin A, Gan Y, Yu A (2014) Higher yield and lower carbon emission by intercropping maize with rape, pea, and wheat in arid irrigation areas. Agron Sustain Dev 34:535-543. https://doi.org/10.1007/s13593-013-0161-x

Chen P, Song C, Liu XM et al (2019) Yield advantage and nitrogen fate in an additive maize-soybean relay intercropping system. Sci Total Environ 657:987-999. https://doi. org/10.1016/j.scitotenv.2018.11.376

Cong WF, Hoffland E, Li L, Six J, Sun JH, Bao XG, Zhang FS, Van Der Werf W (2015) Intercropping enhances soil carbon and nitrogen. Glob Change Biol 21:1715-1726. https://doi.org/10.1111/gcb.12738

Craven D, Isbell F, Manning P et al (2016) Plant diversity effects on grassland productivity are robust to both nutrient enrichment and drought. Philos Trans R Soc B Biol Sci. https://doi.org/10.1098/rstb.2015.0277

Darch T, Giles CD, Blackwell MSA et al (2018) Inter- and intra-species intercropping of barley cultivars and legume species, as affected by soil phosphorus availability. Plant Soil 427:125-138. https://doi.org/10.1007/ s11104-017-3365-z

Dissanayaka DMSB, Maruyama H, Masuda G, Wasaki J (2015) Interspecific facilitation of $\mathrm{P}$ acquisition in intercropping of maize with white lupin in two contrasting soils as influenced by different rates and forms of P supply. Plant Soil 390:223-236. https://doi.org/10.1007/s11104-015-2392-x

Dong N, Tang M, Zhang W et al (2018) Temporal differentiation of crop growth as one of the drivers of intercropping yield advantage. Sci Rep. https://doi.org/10.1038/s41598-018-21414-w
Ehrenfeld JG, Ravit B, Elgersma K (2005) Feedback in the plant-soil system. Annu Rev Environ Resour 30:75-115. https://doi.org/10.1146/annurev.energy.30.050504.144212

Fitzpatrick CR, Gehant L, Kotanen PM, Johnson MTJ (2017) Phylogenetic relatedness, phenotypic similarity and plantsoil feedbacks. J Ecol 105:786-800. https://doi.org/10. 1111/1365-2745.12709

Freschet GT, Aerts R, Cornelissen JHC (2012) A plant economics spectrum of litter decomposability. Funct Ecol 26:5665. https://doi.org/10.1111/j.1365-2435.2011.01913.x

Fustec J, Lesuffleur F, Mahieu S, Cliquet JB (2009) Nitrogen rhizodeposition of Legumes. Sustain Agric 2:869-881. https://doi.org/10.1007/978-94-007-0394-0_38

Gaudin ACM, Tolhurst TN, Ker AP et al (2015) Increasing crop diversity mitigates weather variations and improves yield stability. PLoS ONE 10:1-20. https://doi.org/10. 1371/journal.pone.0113261

German DP, Weintraub MN, Grandy AS et al (2011) Optimization of hydrolytic and oxidative enzyme methods for ecosystem studies. Soil Biol Biochem 43:1387-1397

Gou F, Van IMK, Wang G et al (2016) Yield and yield components of wheat and maize in wheat-maize intercropping in the Netherlands. Eur J Agron 76:17-27. https://doi.org/ 10.1016/j.eja.2016.01.005

Gurr GM, Lu Z, Zheng X, Xu H, Zhu P, Chen G, Yao X, Cheng J, Zhu Z, Catindig JL, Villareal S, Chien HV, Cuong LQ, Channoo C, Chengwattana M, Lan LP, Hai LH, Chaiwong J, Nicol HI, Perovic DJ, Wratten SD, Heong KL (2016) Multi-country evidence that crop diversification promotes ecological intensification of agriculture. Nature Plants 2:16014. https://doi.org/10.1038/nplants.2016.14

Hacker N, Ebeling A, Gessler A et al (2015) Plant diversity shapes microbe-rhizosphere effects on $\mathrm{P}$ mobilisation from organic matter in soil. Ecol Lett 18:1356-1365. https://doi.org/10.1111/ele.12530

Hauggaard-Nielsen H, Jørnsgaard B, Kinane J, Jensen ES (2008) Grain legume - Cereal intercropping: The practical application of diversity, competition and facilitation in arable and organic cropping systems. Renew Agric Food Syst 23:3-12. https://doi.org/10.1017/S17421705070020 25

Heinen R, Hannula ES, De Long JR et al (2020) Plant community composition steers grassland vegetation via soil legacy effects. Ecol Lett 23:973-982. https://doi.org/10. 1111/ele.13497

Ho J, Tumkaya T, Aryal S et al (2019) Moving beyond P values: data analysis with estimation graphics. Nat Methods 16:565-566. https://doi.org/10.1038/s41592-019-0470-3

Huang Y, Chen Y, Castro-Izaguirre N et al (2018) Impacts of species richness on productivity in a large-scale subtropical forest experiment. Science 80(362):80-83. https://doi. org/10.1126/science.aat6405

in't Zandt D, van den Brink A, de Kroon H, Visser EJW (2019) Plant-soil feedback is shut down when nutrients come to town. Plant Soil 439:541-551. https://doi.org/10.1007/ s11104-019-04050-9

Ingerslew KS, Kaplan I (2018) Distantly related crops are not better rotation partners for tomato. J Appl Ecol 55:25062516. https://doi.org/10.1111/1365-2664.13156

Isbell F, Adler PR, Eisenhauer N et al (2017) Benefits of increasing plant diversity in sustainable agroecosystems. 
J Ecol 105:871-879. https://doi.org/10.1111/1365-2745. 12789

Jensen ES, Hauggaard-Nielsen H (2003) How can increased use of biological N2 fixation in agriculture benefit the environment? Plant Soil 252:177-186. https://doi.org/10. 1023/A:1024189029226

Kaplan I, Bokulich NA, Caporaso JG et al (2020) Phylogenetic farming: can evolutionary history predict crop rotation via the soil microbiome? Evol Appl 13:1984-1999. https:// doi.org/10.1111/eva.12956

Karpenstein-Machan M, Stuelpnagel R (2000) Biomass yield and nitrogen fixation of legumes monocropped and intercropped with rye and rotation effects on a subsequent maize crop. Plant Soil 218:215-232

Kassambara A (2020) ggpubr: "ggplot2" Based Publication Ready Plots. https://cran.r-project.org/package=ggpubr

Klinerová T, Dostál P (2019) Nutrient-demanding species face less negative competition and plant-soil feedback effects in a nutrient-rich environment. New Phytol. https://doi. org/10.1111/nph.16227

Kumar A, Shahbaz M, Blagodatskaya E et al (2018) Maize phenology alters the distribution of enzyme activities in soil: field estimates. Appl Soil Ecol 125:233-239. https:// doi.org/10.1016/j.apsoil.2018.02.001

Latati M, Blavet D, Alkama N et al (2014) The intercropping cowpea-maize improves soil phosphorus availability and maize yields in an alkaline soil. Plant Soil 385:181-191. https://doi.org/10.1007/s11104-014-2214-6

Levine JM, HilleRisLambers J (2009) The importance of niches for the maintenance of species diversity. Nature 461:254-257. https://doi.org/10.1038/nature08251

Li L, Li SM, Sun JH et al (2007) Diversity enhances agricultural productivity via rhizosphere phosphorus facilitation on phosphorus-deficient soils. Proc Natl Acad Sci USA 104:1119211196. https://doi.org/10.1073/pnas.0704591104

Li L, Tilman D, Lambers H, Zhang FS (2014) Plant diversity and overyielding: insights from belowground facilitation of intercropping in agriculture. New Phytol 203:63-69

Li B, Li YY, Wu HM et al (2016) Root exudates drive interspecific facilitation by enhancing nodulation and $\mathrm{N} 2$ fixation. Proc Natl Acad Sci USA 113:6496-6501. https://doi.org/ $10.1073 /$ pnas. 1523580113

Li Y, Ma L, Wu P et al (2020) Yield, yield attributes and photosynthetic physiological characteristics of dryland wheat (Triticum aestivum L.)/maize (Zea mays L.) strip intercropping. F Crop Res 248:107656. https://doi.org/10. 1016/j.fcr.2019.107656

Mangiafico S (2020) rcompanion: functions to support extension education program evaluation. https://cran.rproject. org/package $=$ ggpubr

Marx MC, Wood M, Jarvis SC (2001) A microplate fluorimetric assay for the study of enzyme diversity in soils. Soil Biol Biochem 33:1633-1640. https://doi.org/10.1016/ S0038-0717(01)00079-7

McGonigle TP, Miller MH, Evans DG et al (1990) A new method which gives an objective measure of colonization of roots by vesicular-arbuscular mycorrhizal fungi. New Phytol 115:495-501. https://doi.org/10.1111/j.1469-8137. 1990.tb00476.x
Mehrabi Z, Tuck SL (2015) Relatedness is a poor predictor of negative plant-soil feedbacks. New Phytol 205:10711075. https://doi.org/10.1111/nph.13238

Miller EC, Perron GG, Collins CD (2019) Plant-driven changes in soil microbial communities influence seed germination through negative feedbacks. Ecol Evol 9:9298-9311. https://doi.org/10.1002/ece3.5476

Mushonga K, Steyn JM, Swart WJ, Van Der WJE (2020) Plant - soil feedback responses of four dryland crop species under greenhouse conditions. Plant Environ Interact 1:181-195. https://doi.org/10.1002/pei3.10035

Olander LP, Vitousek PM (2000) Regulation of soil phosphatase and chitinase activity by $\mathrm{N}$ and $\mathrm{P}$ availability. Biogeochemistry 49:175-190. https://doi.org/10.1023/A: 1006316117817

Panke-Buisse K, Poole AC, Goodrich JK et al (2015) Selection on soil microbiomes reveals reproducible impacts on plant function. ISME J 9:980-989. https://doi.org/10. 1038/ismej.2014.196

Phillips JM, Hayman DS (1970) Improved procedures for clearing roots and staining parasitic and vesiculararbuscular mycorrhizal fungi for rapid assessment of infection. Trans Br Mycol Soc 55:158-161. https://doi. org/10.1016/s0007-1536(70)80110-3

Png GK, Lambers H, Kardol P et al (2019) Biotic and abiotic plant-soil feedback depends on nitrogen-acquisition strategy and shifts during long-term ecosystem development. J Ecol 107:142-153. https://doi.org/10.1111/ 1365-2745.13048

Polley HW, Wilsey BJ, Derner JD (2003) Do species evenness and plant density influence the magnitude of selection and complementarity effects in annual plant species mixtures? Ecol Lett 6:248-256. https://doi.org/10. 1046/j.1461-0248.2003.00422.x

Rillig MC, Ryo M, Lehmann A et al (2019) The role of multiple global change factors in driving soil functions and microbial biodiversity. Science 366:886-890. https:// doi.org/10.1126/science.aay 2832

Roy J, van Duijnen R, Leifheit EF et al (2021) Legacy effects of pre-crop plant functional group on fungal root symbionts of barley. Ecol Appl. https://doi.org/10.1002/EAP. 2378

Scalise A, Tortorella D, Pristeri A et al (2015) Legume-barley intercropping stimulates soil $\mathrm{N}$ supply and crop yield in the succeeding durum wheat in a rotation under rainfed conditions. Soil Biol Biochem 89:150-161. https:// doi.org/10.1016/j.soilbio.2015.07.003

Schmid MW, Moorsel SJ Van, Hahl T et al (2020) Plant diversity and community age shape soil microbial communities. 1-52. https://doi.org/10.1101/2020.07.08.193409

Schnitzer SA, Klironomos JN, HilleRisLambers J et al (2011) Soil microbes drive the classic plant diversity-productivity pattern. Ecology 92:296-303

Sileshi G, Akinnifesi FK, Ajayi OC et al (2008) Meta-analysis of maize yield response to woody and herbaceous legumes in Sub-Saharan Africa. Plant Soil. https://doi.org/10. 1007/s11104-008-9547-y

Smilauer P, Kosnar J, Kotilinek M, Smilauerov M (2020) Contrasting effects of host identity, plant community, and 
local species pool on the composition and colonization levels of arbuscular mycorrhizal fungal community in a temperate grassland. New Phytol 225:461-473. https:// doi.org/10.1111/nph.16112

Su BY, Song YX, Song C et al (2014) Growth and photosynthetic responses of soybean seedlings to maize shading in relay intercropping system in Southwest China. Photosynthetica 52:332-340. https://doi.org/10.1007/ s11099-014-0036-7

Team RC (2020) R: a language and environment for statistical computing. Vienna, Austria: R Foundation for Statistical Computing. Retrieved from https://www.r-project.org/

Temperton VM, Mwangi PN, Scherer-Lorenzen M et al (2007) Positive interactions between nitrogen-fixing legumes and four different neighbouring species in a biodiversity experiment. Oecologia 151:190-205. https://doi.org/10. 1007/s00442-006-0576-z

Tilman D, Balzer C, Hill J, Befort BL (2011) Global food demand and the sustainable intensification of agriculture. Proc Natl Acad Sci USA 108:20260-20264. https://doi. org/10.1073/pnas.1116437108

Treseder KK (2004) A meta-analysis of mycorrhizal responses to nitrogen, phosphorus, and atmospheric $\mathrm{CO}_{2}$ in field studies. New Phytol 164:347-355. https://doi.org/10. 1111/j.1469-8137.2004.01159.x

Uroz S, Courty PE, Oger P (2019) Plant symbionts are engineers of the plant-associated microbiome. Trends Plant Sci 24:905-916. https://doi.org/10.1016/j.tplants.2019.06. 008

Van der Putten WH, Bardgett RD, Bever JD et al (2013) Plantsoil feedbacks: the past, the present and future challenges. J Ecol 101:265-276. https://doi.org/10.1111/1365-2745. 12054

Vance E, Brookes PC, Jenkinson DS (1987) An extraction method for measuring soil microbial biomass C. Soil Biol Biochem 19:703-707

Venables WN, Ripley BD (2002) Modern applied Statistics with S, 4th Ed. Springer, NewYork. https://www.stats.ox. ac.uk/pub/MASS4/

Vierheilig H, Coughlan AP, Wyss URS, De Recherche C (1998) Ink and vinegar, a simple staining technique for arbuscularmycorrhizal fungi. Appl Environ Microbiol 64:5004-5007

Wang ZG, Bao XG, Li XF et al (2015) Intercropping maintains soil fertility in terms of chemical properties and enzyme activities on a timescale of one decade. Plant Soil 391:265-282. https://doi.org/10.1007/s11104-015-2428-2
Wang GZ, Li HG, Christie P et al (2017) Plant-soil feedback contributes to intercropping overyielding by reducing the negative effect of take-all on wheat and compensating the growth of faba bean. Plant Soil 415:1-12. https://doi.org/ 10.1007/s11104-016-3139-z

Wang G, Bei S, Li J et al (2020) Soil microbial legacy drives crop diversity advantage: linking ecological plant-soil feedback with agricultural intercropping. J Appl Ecol. https://doi.org/10.1111/1365-2664.13802

Wezel A, Casagrande M, Celette F et al (2014) Agroecological practices for sustainable agriculture. A Review Agron Sustain Dev 34:1-20. https://doi.org/10.1007/ s13593-013-0180-7

Wickham H (2016) ggplot: elegant graphics for data analysis. Springer, New York

Witt C, Gaunt JL, Galicia CC et al (2000) A rapid chloroformfumigation extraction method for measuring soil microbial biomass carbon and nitrogen in flooded rice soils. Biol Fertil Soils 30:510-519. https://doi.org/10.1007/ s003740050030

Yang W, Li Z, Wang J et al (2013) Crop yield, nitrogen acquisition and sugarcane quality as affected by interspecific competition and nitrogen application. F Crop Res 146:4450. https://doi.org/10.1016/j.fcr.2013.03.008

Yu Y, Stomph TJ, Makowski D, van der Werf W (2015) Temporal niche differentiation increases the land equivalent ratio of annual intercrops: A meta-analysis. F Crop Res 184:133-144. https://doi.org/10.1016/j.fcr.2015.09.010

Zhang D, Zhang C, Tang X et al (2016) Increased soil phosphorus availability induced by faba bean root exudation stimulates root growth and phosphorus uptake in neighbouring maize. New Phytol 209:823-831. https://doi.org/ 10.1111/nph.13613

Zhang WP, Liu GC, Sun JH et al (2017) Temporal dynamics of nutrient uptake by neighbouring plant species: evidence from intercropping. Funct Ecol 31:469-479. https://doi. org/10.1111/1365-2435.12732

Zuur AF, Ieno EN, Elphick CS (2010) A protocol for data exploration to avoid common statistical problems. Methods Ecol Evol 1:3-14. https://doi.org/10.1111/j.2041210X.2009.00001.x

Publisher's note Springer Nature remains neutral with regard to jurisdictional claims in published maps and institutional affiliations. 